\title{
Project Monitoring ANd Control Measures IN CMMI
}

\author{
Mahmoud Khraiwesh \\ Faculty of Science and Information Technology \\ Zarqa University \\ Zarqa - Jordan
}

\begin{abstract}
Project monitoring and control process is an important process in developing any computer information system. Monitoring and Control provides an understanding of the project's progress so that when the project deviates significantly from the plan appropriate corrective actions can be taken. This research will identify general measures for the specific goals and its specific practices of Project Monitoring and Control Process Area in Capability Maturity Model Integration (CMMI). CMMI is developed in USA by Software Engineering Institute (SEI) in Carnegie Mellon University. CMMI is a framework for assessment and improvement of computer information systems. The procedure we used to determine the measures is to apply the Goal Questions Metrics (GQM) approach to the two specific goals and its ten specific practices of Project Monitoring and Control Process Area in CMMI.
\end{abstract}

\section{KEYWORDS}

Monitoring, control, Measures, CMMI, GQM.

\section{INTRODUCTION}

Project monitoring and control is one of the most important activities in the modern software development process. Without an objective and realistic monitoring and control of software project, there is no appropriate visibility of progress and the development of software process cannot be managed effectively.

We will define measures for the project monitoring and control process. The set of measures that will be defined in this research provides the organization with better insight into project monitoring and control of the computer information systems so the system development will be compatible with the plan.

Since software becomes common and embedded in nearly every thing we do and increasingly govern our society and our world. We have to make sure that systems run in a better way as we intend. A software project measures is the discipline that ensures that we stay in control. Measurements of a software project apply to products, processes, and people [10].

Software project monitoring and control is critical to detect the deviation of the project plan and to take appropriate actions, when needed. However, to determine the action which should be taken is not an easy task. We will provide important knowledge to project managers in order to improve monitoring and control activities of the projects [3].

DOI : 10.5121/ijcsit.2013.5503 
International Journal of Computer Science \& Information Technology (IJCSIT) Vol 5, No 5, October 2013

Successful software project development requires companies to pay special attention to monitor and control the project activities during the project's life cycle. If monitoring and control activities are not done well, the productivity of the project decreases [35]. There will be an emphasis on monitoring and control of the project against the planned progress. There is a need for project managers to evaluate the application being developed according to an appropriate management approach [28].

Development of software involves both managerial and technical decisions, so we have to improve project management, such as planning, monitoring, and control projects. It is still difficult to determine which mechanisms are useful to control large software development projects [32]. Software processes and products improvements would have to be planned and monitored starting from strategic level to the organization daily operations [2].

Nowadays we know the fact that software measurement helps us to better understand, evaluate, and control the processes, products, and software projects from the perspective of evaluating, tracking, forecasting, controlling and understanding [14]. A good measurement process can provide organizations to make better and timelier decisions to achieve success in software systems [19].

Measurement is a usefully support tool for software management [24]. Measurement is the key to effective manage a process. Measurement is a mechanism for evaluating, characterizing, and predicting for various software products and processes [4]. The efficient way to improve any software process is to measure specific attributes of the process, develop a set of related metrics based on these attributes of the process, and then use these metrics to provide indicators that will lead to improvement strategy. Measurements of software perform an important role in understanding and controlling of software development products and processes [23].

In measurement numbers or symbols are assigned to attributes of selected entities in the real world in such a way to characterize the attributes by some defined rules [13]. Measurement is important for three main activities: understanding, controlling and improvement [15]. We use measurements to assess goals achievement, to determine status according to plans, to gain understanding of processes, products, environments and resources, to establish principles for comparisons with future assessments and follow improvement efforts [29]. The main measurement objective is to monitor the performance of software process [27].

Software measurement is now in a status in which terminologies, methods and principles are still being defined and combined. We should not look forward to find quantitative laws that are mostly valid and applicable, and have the same accuracy and precisions as the laws of physics, for instance. As a result, the identification of universally valid and applicable measures may be long term and ideal research goal, which cannot be achieved in the closer future, if at all [8]. Software engineering measurements is not grounded in the basic quantitative laws of physics. Explicit measurements such as mass, voltage, temperature, or velocity are uncommon in the software engineering world. Because software metrics and measures are often indirect, they are open to controversy [31]. There is a lack of an agreed-upon framework of validation metrics [17]. The purpose of software measures is to improve the software process [11].

The Software Engineering Institute (SEI) initiated a study for determining the capabilities of software contractors in the mid-1980s. The result of this capability assessment was the Software Capability Maturity Model for Software (CMM/SW) [30]. There are other capability maturity 
International Journal of Computer Science \& Information Technology (IJCSIT) Vol 5, No 5, October 2013

models were followed the CMM software framework, such as the People Capability Maturity Model (P- CMM) [9].

Software Engineering Institute (SEI) and many organizations from industry are joined together to develop the CMMI software framework, a set of integrated CMMI models.

In United State the Department of Defense and other parts of the government use the Capability Maturity Model Integrated (CMMI) for process improvement to reduce the risk of poor implementation of contractors. The CMMI is a widely used and relatively complete framework for improving the processes of organizations that build complex engineering products [33].

Materials included in the CMMI model are [1]:

1. Materials which help you evaluate the contents of your processes, information that is essential for your managerial activities and technical support activities.

2. Materials which help you improve process performance, information that you use to increase the capability in our organizations.

Through the process of choosing CMMI, we try to attain the following objectives: 1- to improve project management capability; 2- to enhance product quality; 3 - to increase productivity and cost down; 4- to improve the capability of estimating the project budget and schedule; 5 - to increase customer satisfaction [25].

CMMI is a comprehensive model. CMMI involves several topics of knowledge in software production, defined many Process Areas (PA), generic and specific goals, generic and specific practices, and a lot of work products. CMMI is used to improve processes, increase productivity and keep competitiveness of an organization [38].

Within each process area in $\mathrm{CMMI} / \mathrm{SW}$, there are one or more generic goals with generic practices and specific goals with specific practices. A specific goal relates to a process area and focuses on the related characteristics that describe what must be implemented to accept the process area. A specific practice is considered as an important activity in achieving the associated specific goal. However, specific practices are recognized by CMMI that a specific practice is the goal rather than the way that we reach the goal [36].

Software process improvement becomes the key to the existence of many software development organizations. CMMI can help set process improvement goals and provide guidance for quality processes. CMMI supports process and product improvement, reduces redundancy and eliminates inconsistency because of using multiple standalone models. The CMMI is designed to cover all processes in the software development cycle and cover a wide range of products and systems [37].

The Goal-Question-Metric (GQM) is an approach to process and metrics, it was developed by Basili and Weiss [6] as an approach for identifying meaningful metrics for software development processes. It has proven that it is an effective approach to selecting and implementing metrics.

This paper defines measures for the two specific goals and its ten specific practices of Project Monitoring and Control which is one of the process areas in level 2 in CMMI-SW (Staged Representation) model. Measures will be compatible with the ten specific practices associated 
International Journal of Computer Science \& Information Technology (IJCSIT) Vol 5, No 5, October 2013

with the two specific goals of Project Monitoring and Control PA. The measures will be identified by applying the Goal-Question-Metrics (GQM) approach to the two specific goals and its ten specific practices of Project Monitoring and Control PA. The defined measures will be helpful to us to evaluate and control the software products and processes.

The remainder of the paper is arranged as the following: section 2 describes the relative work in software development measurement for the CMMI/SW, section 3 presents an overview of the $\mathrm{CMMI} / \mathrm{SW}$, section 4 presents an overview of the (GQM), section 5 describes the application of the (GQM) to the CMMI/SW and defines the measures, section 6 describes the validity and reliability of the defined measures for Project Monitoring and control process area, and section 7 presents conclusions.

\section{RELATED WORK}

Many software measures studies have been proposed in the literature, some of them are [7] [16] [18] [20] [21] [22] [26] [30]. The most related to our work are [7] [26] [30] [20] [21] and [22]. Baumert and McWhinney [7] provide a set of indicators that are convenient with the measurement practice (a common features) described in the Capability Maturity Model for $\mathrm{CMM} / \mathrm{SW}$. These indicators cover thirteen categories, categories don't occur at all of the maturity levels. They don't concentrate on a specific process. Baumert and McWhinney work was related to CMM not CMMI.

Paulk, Weber, Garcia, Crissis and Bush [30] provide a set of examples of measurements in measurement practice (one of the common features) of the Capability Maturity Model for Software (CMM/SW) in Key Process Areas (KPAs). They defined a few examples related to requirements management KPA. They don't focus on a specific process. Their work was based on $\mathrm{CMM} / \mathrm{SW}$ not CMMI/SW. Loconsole [26] provided measures for the Requirements Management Key Process Area of the CMM/SW. Loconsole's work was based on CMM/SW not CMMI/SW. Khraiwesh [20] [21] [22] provided measurements for Requirements Validation, Risk Management, and Project Planning process areas of the CMMI/SW.

This paper defines a set of general measures that are focused on a specific PA, which is Project Monitoring and Control PA of the CMMI/SW. Measures are for the two specific goals and its ten specific practices of Project Monitoring and control PA.

\section{OVERVIEW OF THE CMMI-SW}

The CMMI/SW (Staged Representation) consists of five maturity levels: Initial, Managed, Defined, Quantitatively Managed and Optimizing. The five maturity levels are shown in Figure 1. Each maturity level is composed of several process areas except Level1 [34].

For each process area in CMMI/SW, there are generic goals with generic practices and one or more specific goals with specific practices. Generic goals are related to the institutionalization of proper practices, they called generic because the same goal statement appears in multiple process areas as shown in figure 2. The specific goal is applied to the process area and addressed the features that only describe what must be implemented to satisfy the process area. The specific practice is an activity that must be implemented to realize the associated specific goal [34]. 
International Journal of Computer Science \& Information Technology (IJCSIT) Vol 5, No 5, October 2013

The purpose of Project Monitoring and control (PMC) is to provide an understanding for the project progress and to take a suitable action when the project deviates from the plan. The documented plan is the basis for monitoring activities. Progress is mainly determined by comparing the plan to work product, effort, cost, and schedule [34].

The following are the specific goals related to Project Monitoring and Control process area and the specific practices related to each specific goal:

1- Monitor the project against the plan.

1.1 Monitor project planning parameters.

1.2 Monitor commitments.

1.3 Monitor project risks.

1.4 Monitor data management.

1.5 Monitor stakeholder involvement.

1.6 Conduct progress reviews.

1.7 Conduct milestone reviews.

2- Manage corrective action to closure.

2.1 Analyze issues.

2.2 Take corrective action.

2.3 Manage corrective actions. 


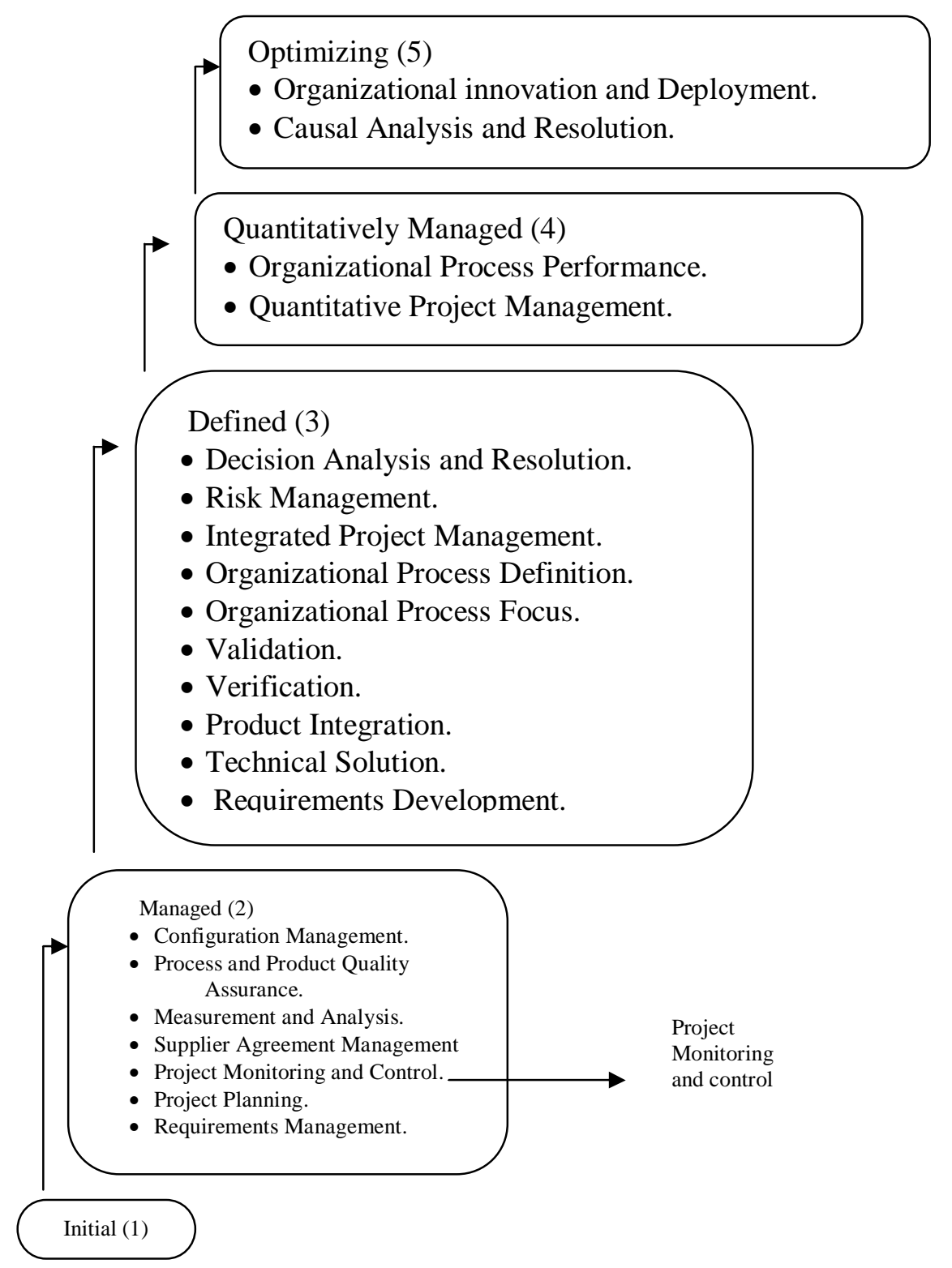

Figure 1. five levels with Process Areas in CMMI.

\section{OVERVIEW OF THE GQM}

The Goal/Question/Metric (GQM) paradigm is a process that helps organizations to focus the measurement activity on their goals. The GQM states that an organization should have identified goals in mind before they collected data [4]. The more mature your process is, the more that it is visible and therefore measurable. The GQM does not identify concrete goals, it is rather a structure that defines goals and refines them into a set of quantifiable questions, and these questions imply a specific set of measures and collected data in order to achieve these goals. 
International Journal of Computer Science \& Information Technology (IJCSIT) Vol 5, No 5, October 2013

The GQM paradigm consists of three steps:

1. Define a set of goals related to the needs of the organization and its projects. Determine what should be learned or improved. We can define the goals in terms of purpose, perspective, and environment. Measurement goals should be defined in a clear structure and an understandable way. We do this by specifying the purpose (what object and why), viewpoint (what aspect and who), and characteristics of context [5].

2. Generate a set of quantifiable questions. The defined goals are transferred into quantifiable questions with a measurement focus. Basili and Rombach [4] provide different sets of guidelines to classify questions associated to processes or products.

3. Define a set of measures that fit the quantitative information we need to answer the generated quantifiable questions. In this step, we define the measures suitable to provide information to answer the questions and relate them to each question. Several metrics may be generated from a single goal. Several measurements may be needed to answer one question. One measurement may apply to more than one question.

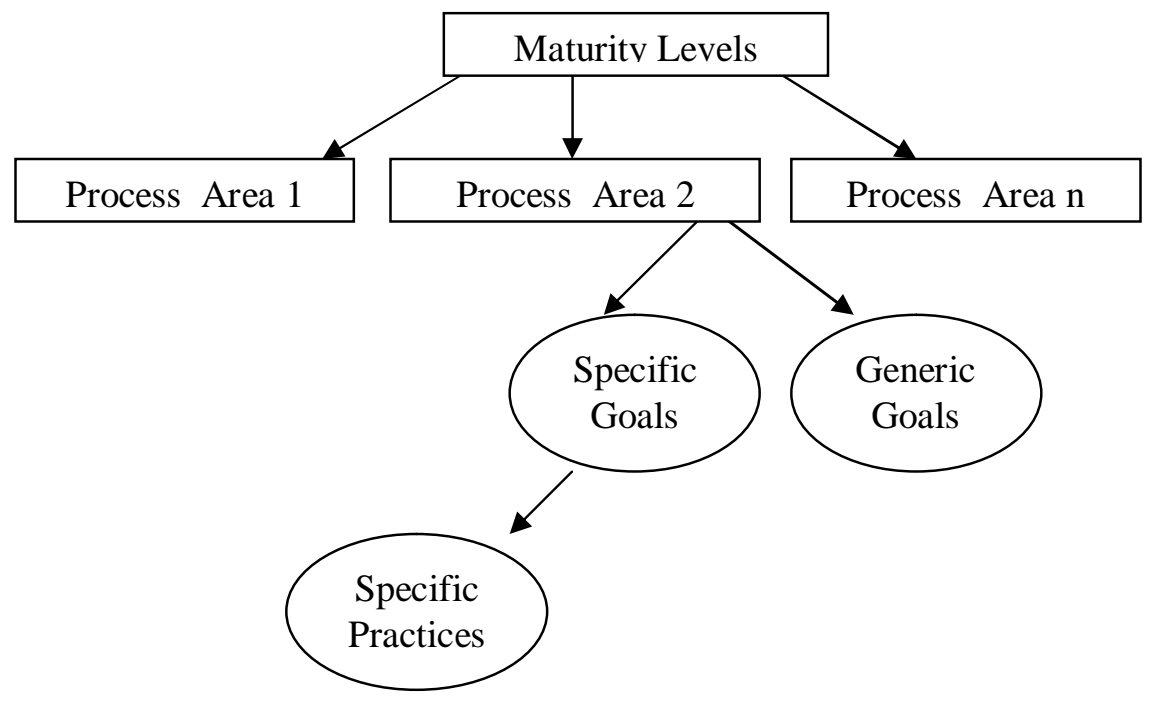

Figure 2. specific and generic goals

\section{APPlying GQM to The CMMI-SW}

The CMMI/SW defines two specific goals for Project Monitoring and Control PA. There are ten specific practices related to the specific goals. We consider the specific practices as goals. We will apply the GQM on the ten specific practices.

The ten specific practices associated with Project Monitoring and Control process area are:

1-Monitor Project Planning Parameters: Monitor actual values of project planning parameters against the project plan

2-Monitor Commitments: Monitor commitments against those identified in the project plan. 
International Journal of Computer Science \& Information Technology (IJCSIT) Vol 5, No 5, October 2013

3-Monitor Project Risks: Monitor risks against those identified in the project plan.

4-Monitor Data Management: Monitor the management of project data against the project plan.

5-Monitor Stakeholder Involvement: Monitor stakeholder involvement against the project plan.

6-Conduct Progress Reviews: Periodically review the project's progress, performance, and issues.

7-Conduct Milestone Reviews: Review the project's accomplishments and results at selected project milestones.

8-Analyze Issues: Collect and analyze issues and determine corrective actions to address them.

9- Take Corrective Action: Take corrective action on identified issues.

10-Manage Corrective Actions: Manage corrective actions to closure.

These ten specific practices can be used as goals for the first step of the GQM. The second step in the GQM paradigm is to generate a set of quantifiable questions related to the ten specific practices. The third step of the GQM is to define a set of measures that provide the necessary quantitative information to answer the generated questions. The typical work products and sub practices which are found in each of the ten specific practices are take in consideration when we define the measures.

A set of questions and measures are given in the following tables, table 1 through table 10, each table related to one specific practice. There are overlaps between the questions and between the measures. The same measure can be used to provide information to answer different generated questions.

\subsection{Measures for specific practice 1}

Monitor Project Planning Parameters: Monitor actual values of project planning parameters against the project plan

A set of questions and measures are given in the next table concerning specific practice 1.

Table 1. Set of questions and measures concerning practice 1.

\begin{tabular}{|c|c|c|}
\hline & Questions & Measures \\
\hline Q1 & $\begin{array}{l}\text { Do you monitor the project planning } \\
\text { parameters to the project plan? } \\
\text { (Project plan parameters are indicators of } \\
\text { the project progress, it includes } \\
\text { attributes of work products, tasks, costs, } \\
\text { efforts and schedule. Attributes of work } \\
\text { product include size, complexity, and } \\
\text { availability) } \\
\text { Monitoring involves the measure of the } \\
\text { actual parameter values of project } \\
\text { planning, comparing these values to that } \\
\text { estimated in the plan, and then identify } \\
\text { the deviation. }\end{array}$ & $\begin{array}{l}\text { - Monitoring the project planning } \\
\text { parameters to the project plan. } \\
\text { - \# Actual parameters of project planning. } \\
\text { - \# Attributes of work products. } \\
\text { - \# Attributes of tasks. } \\
\text { - \# Attributes of costs. } \\
\text { - \# Attributes of efforts. } \\
\text { - \# Attributes of schedule. } \\
\text { - \# Parameters of estimated plan. } \\
\text { (\# means number of) }\end{array}$ \\
\hline Q2 & $\begin{array}{l}\text { Do you monitor the project progress } \\
\text { against the schedule? }\end{array}$ & $\begin{array}{l}\text { - Monitoring the project progress against } \\
\text { the schedule. }\end{array}$ \\
\hline
\end{tabular}


International Journal of Computer Science \& Information Technology (IJCSIT) Vol 5, No 5, October 2013

\begin{tabular}{|c|c|c|}
\hline Q3 & $\begin{array}{l}\text { Do you monitor periodically the actual } \\
\text { completion of activities and milestones? }\end{array}$ & $\begin{array}{l}\text { - Monitoring periodically the actual } \\
\text { completion of activities and milestones. } \\
\text { - \# Actual activities. } \\
\text { - \# Actual milestones. }\end{array}$ \\
\hline Q4 & $\begin{array}{l}\text { Do you compare the actual completion } \\
\text { of activities and milestones against the } \\
\text { plan schedule of the project? }\end{array}$ & $\begin{array}{l}\text { - Comparing the actual completion of } \\
\text { activities and milestones against the plan } \\
\text { schedule of the project. } \\
\text { - \# Activities in the estimated plan. } \\
\text { - \# Milestones in the estimated plan. }\end{array}$ \\
\hline Q5 & $\begin{array}{l}\text { Do you identify significant deviations } \\
\text { for the plan schedule estimates of the } \\
\text { project? }\end{array}$ & $\begin{array}{l}\text { - Identifying significant deviations for the } \\
\text { plan schedule estimates of the project. } \\
\text { - \# deviations. }\end{array}$ \\
\hline Q6 & $\begin{array}{l}\text { Do you periodically measure the actual } \\
\text { effort, costs expended and staff } \\
\text { assigned? }\end{array}$ & $\begin{array}{l}\text { - Measuring periodically the actual effort, } \\
\text { costs expended and staff assigned. }\end{array}$ \\
\hline Q7 & $\begin{array}{l}\text { Do you compare the actual effort, costs, } \\
\text { staffing, and training to the budget of } \\
\text { the project plan? }\end{array}$ & $\begin{array}{l}\text { - Comparing the actual effort, costs, } \\
\text { staffing, and training to the budget of the } \\
\text { project plan. }\end{array}$ \\
\hline Q8 & $\begin{array}{l}\text { Do you identify attributes of work } \\
\text { products and tasks? } \\
\text { (Attributes include: si3e, availability, } \\
\text { complexity, function, and service } \\
\text { level). }\end{array}$ & $\begin{array}{l}\text { Identifying attributes of work products } \\
\text { and tasks. } \\
\text { - \# Attributes of work products. } \\
\text { - \# Attributes of tasks. }\end{array}$ \\
\hline Q9 & $\begin{array}{l}\text { Do you monitor the attributes of work } \\
\text { products and tasks? }\end{array}$ & $\begin{array}{l}\text { Monitoring the attributes of work } \\
\text { products and tasks. }\end{array}$ \\
\hline $\begin{array}{l}\mathrm{Q} 1 \\
0\end{array}$ & $\begin{array}{l}\text { Do you compare the actual attributes of } \\
\text { work products and tasks to the project } \\
\text { plan estimates? }\end{array}$ & $\begin{array}{l}\text { - Comparing the actual attributes of work } \\
\text { products and tasks to the project plan } \\
\text { estimates. } \\
\text { - \# Deviations. }\end{array}$ \\
\hline $\begin{array}{l}\text { Q1 } \\
1\end{array}$ & $\begin{array}{l}\text { Do you monitor resources provided and } \\
\text { used? } \\
\text { (Resources include: computers, } \\
\text { peripherals, software, networks, project } \\
\text { staff and security environment)? }\end{array}$ & $\begin{array}{l}\text { - Monitoring resources provided and used. } \\
\text { - \# Resources. }\end{array}$ \\
\hline $\begin{array}{l}\text { Q1 } \\
2\end{array}$ & $\begin{array}{l}\text { Do you monitor the knowledge and } \\
\text { skills of the project staff? }\end{array}$ & $\begin{array}{l}\text { - Monitoring the knowledge and skills of } \\
\text { the project staff } \\
\text { - \# Project staff. } \\
\text { - Knowledge and skill level. }\end{array}$ \\
\hline $\begin{array}{l}\text { Q1 } \\
3\end{array}$ & $\begin{array}{l}\text { Do you measure the acquisition of } \\
\text { knowledge and skills by the project } \\
\text { staff? }\end{array}$ & $\begin{array}{l}\text { - Measuring the acquisition of knowledge } \\
\text { and skills by the project staff. } \\
\text { - } \% \text { Acquisition of knowledge and skills. }\end{array}$ \\
\hline
\end{tabular}


International Journal of Computer Science \& Information Technology (IJCSIT) Vol 5, No 5, October 2013

\begin{tabular}{|l|l|l|}
\hline Q1 & $\begin{array}{l}\text { Do you measure the actual training } \\
\text { obtained to that documented in the plan } \\
\text { of the project? }\end{array}$ & $\begin{array}{l}\text { - Measuring the actual training obtained to } \\
\text { that documented in the plan of the } \\
\text { project. } \\
\text {-\% Deviations. }\end{array}$ \\
\hline
\end{tabular}

\subsection{Measures for specific practice 2}

Monitor Commitments: Monitor commitments against those identified in the project plan. A set of questions and measures is given in the next table concerning specific practice 2 .

Table 2. Set of questions and measures concerning specific practice 2.

\begin{tabular}{|l|l|l|}
\hline & Questions & Measures \\
\hline Q1 & Do you regularly review commitments? & $\begin{array}{l}\text { - Reviewing commitments regularly. } \\
\text { - \# Commitments. }\end{array}$ \\
\hline Q2 & $\begin{array}{l}\text { Do you identify the unsatisfied } \\
\text { commitments? }\end{array}$ & $\begin{array}{l}\text { - Identifying the unsatisfied } \\
\text { commitments. } \\
\text { - \# unsatisfied commitments. }\end{array}$ \\
\hline Q3 & $\begin{array}{l}\text { Do you document the results of } \\
\text { commitment reviews? }\end{array}$ & $\begin{array}{l}\text { - Documenting the results of commitment } \\
\text { reviews. }\end{array}$ \\
\hline
\end{tabular}

\subsection{Measures for specific practice 3}

Monitor Project Risks: Monitor risks against those identified in the project plan. A set of questions and measures is given in the next table concerning specific practice 3.

Table 3. Set of questions and measures concerning specific practice 3

\begin{tabular}{|l|l|l|}
\hline & Questions & Measures \\
\hline Q1 & $\begin{array}{l}\text { Do you review periodically the } \\
\text { documented risks in the context of the } \\
\text { current status of the project? }\end{array}$ & $\begin{array}{l}\text { - Reviewing periodically the documented } \\
\text { risks in the context of the current status } \\
\text { of the project. } \\
\text { \# \# Documented risks. }\end{array}$ \\
\hline Q2 & $\begin{array}{l}\text { Do you identify and analyze the new } \\
\text { risks? }\end{array}$ & $\begin{array}{l}\text { - Identifying and analyze the new risks. } \\
\text { Q3 New risks. }\end{array}$ \\
\hline Q3 & $\begin{array}{l}\text { Do you communicate the risk status to } \\
\text { the relevant stakeholders? } \\
\text { (Examples of risk status include: A } \\
\text { change in the probability that the risk } \\
\text { occurs and change in the risk priority). }\end{array}$ & $\begin{array}{l}\text { Communicating the risk status to the } \\
\text { relevant stakeholders. }\end{array}$ \\
\hline
\end{tabular}


International Journal of Computer Science \& Information Technology (IJCSIT) Vol 5, No 5, October 2013

\subsection{Measures for specific practice 4}

Monitor Data Management: Monitor the management of project data against the project plan.A set of questions and measures is given in the next table concerning specific practice 4 .

Table 4. Set of questions and measures concerning practice 4

\begin{tabular}{|c|c|c|}
\hline & Questions & Measures \\
\hline Q1 & $\begin{array}{l}\text { Do you review periodically data } \\
\text { management activities to their } \\
\text { description plan? } \\
\text { (Data are various forms of } \\
\text { documentation required to support } \\
\text { program. Forms of data include: reports, } \\
\text { manuals, files, charts, etc). }\end{array}$ & $\begin{array}{l}\text { - Reviewing periodically data } \\
\text { management activities to their } \\
\text { description plan. } \\
\text { - \# Data management activities }\end{array}$ \\
\hline Q2 & $\begin{array}{l}\text { Do you identify significant issues and } \\
\text { their impacts? } \\
\text { (Significant issue such as when } \\
\text { stakeholders don't access to needed } \\
\text { project data to fulfill their roles). }\end{array}$ & $\begin{array}{l}\text { - Identifying significant issues and their } \\
\text { impacts. } \\
\text { - \# Significant issues. }\end{array}$ \\
\hline
\end{tabular}

\subsection{Measures for specific practice 5}

Monitor Stakeholder Involvement: Monitor stakeholder involvement against the project plan. A set of questions and measures is given in the following table concerning specific practice 5 .

Table 5. Set of questions and measures concerning specific practice 5

\begin{tabular}{|l|l|l|}
\hline Q1 & $\begin{array}{l}\text { Questions } \\
\text { to ensure that appropriate interactions } \\
\text { occur? }\end{array}$ & $\begin{array}{l}\text { Measures } \\
\text { - Monitoring stakeholder involvement to } \\
\text { occur. } \\
\text { of that appropriate interactions }\end{array}$ \\
\hline Q2 & $\begin{array}{l}\text { Do you review periodically the status of } \\
\text { stakeholder involvement? } \\
\text { (Strong, moderate, weak) }\end{array}$ & $\begin{array}{l}\bullet \text { Reviewing periodically the status of } \\
\text { stakeholder involvement. } \\
\text { - Involvement status. }\end{array}$ \\
\hline Q3 & $\begin{array}{l}\text { Do you identify the significant issues and } \\
\text { their impacts? }\end{array}$ & $\begin{array}{l}\bullet \text { Identifying the significant issues and } \\
\text { their impacts. } \\
\bullet \text { \# significant issues. }\end{array}$ \\
\hline Q4 & $\begin{array}{l}\text { Do you document the results of } \\
\text { stakeholder involvement status } \\
\text { reviews? }\end{array}$ & $\begin{array}{l}\text { Documenting the results of stakeholder } \\
\text { involvement status reviews. }\end{array}$ \\
\hline
\end{tabular}


International Journal of Computer Science \& Information Technology (IJCSIT) Vol 5, No 5, October 2013

\subsection{Measures for specific practice 6}

Identify Project Risks: Identify and analyze project risks.

A set of questions and measures is given in the next table concerning specific practice 6 .

Table 6. Set of questions and measures concerning practice 6

\begin{tabular}{|c|c|c|}
\hline & Questions & Measures \\
\hline Q1 & $\begin{array}{l}\text { Do you regularly communicate status of } \\
\text { activities and work products to relevant } \\
\text { stakeholders? }\end{array}$ & $\begin{array}{l}\text { - Communicating status of activities and } \\
\text { work products to relevant stakeholders. } \\
\text { - \# Activities to relevant stakeholders. } \\
\text { - \# Work products to relevant stakeholders. }\end{array}$ \\
\hline Q2 & $\begin{array}{l}\text { Do you identify and document significant } \\
\text { derivations from the plan? }\end{array}$ & $\begin{array}{l}\text { - Identifying and documenting significant } \\
\text { derivations from the plan. } \\
\text { - \# Deviations from the plan. }\end{array}$ \\
\hline Q3 & $\begin{array}{l}\text { Do you document change requests and } \\
\text { the identified problems in work products } \\
\text { and processes? }\end{array}$ & $\begin{array}{l}\text { - Documenting change requests and the } \\
\text { identified problems in work products and } \\
\text { processes. } \\
\text { - \# Change requests. } \\
\text { - \# Identified problems. }\end{array}$ \\
\hline Q4 & $\begin{array}{l}\text { Do you track change requests and } \\
\text { problem reports to closure? }\end{array}$ & $\begin{array}{l}\text { - Tracking change requests and problem } \\
\text { reports to closure. } \\
\text { - Track status (tracked to closure or not). }\end{array}$ \\
\hline
\end{tabular}

\subsection{Measures for specific practice 7}

Conduct Progress Reviews: Periodically review the project's progress, performance, and issues. set of questions and measures is given in the next table concerning specific practice 7.

Table 7. Set of questions and measures concerning specific practice 7

\begin{tabular}{|c|c|c|}
\hline & Questions & Measures \\
\hline Q1 & $\begin{array}{l}\text { Do you conduct milestone reviews with } \\
\text { relevant stakeholders at meaningful } \\
\text { points in the schedule of the project? } \\
\text { (milestones are preplanned events at } \\
\text { which a thorough status review is } \\
\text { conducted to check that stakeholder } \\
\text { requirements are being met) }\end{array}$ & $\begin{array}{l}\text { - Conducting milestone reviews with } \\
\text { relevant stakeholders at meaningful } \\
\text { points in the schedule of the project. } \\
\text { - \# Milestones. }\end{array}$ \\
\hline Q2 & $\begin{array}{l}\text { Do you review commitments, the plan, } \\
\text { status, and risks of the project? }\end{array}$ & $\begin{array}{l}\text { - Reviewing commitments, the plan, status, } \\
\text { and risks of the project. } \\
\text { - \# Commitments. } \\
\text { - \# Risks. }\end{array}$ \\
\hline
\end{tabular}


International Journal of Computer Science \& Information Technology (IJCSIT) Vol 5, No 5, October 2013

\begin{tabular}{|l|l|l|}
\hline Q3 & $\begin{array}{l}\text { Do you identify and document significant } \\
\text { issues and their impacts? }\end{array}$ & $\begin{array}{l}\text { - Identifying and documenting significant } \\
\text { issues and their impacts. }\end{array}$ \\
\hline Q4 & Do you track action items to closure? & $\begin{array}{l}\text { - Tracking action items to closure. } \\
\text { - Track status (tracked to closure or not). }\end{array}$ \\
\hline
\end{tabular}

\subsection{Measures for specific practice 8}

Analyze Issues: Collect and analyze issues and determine corrective actions to address them. A set of questions and measures is given in the next table concerning specific practice 8 .

Table 8. Set of questions and measures concerning specific practice 8

\begin{tabular}{|l|l|l|}
\hline & Questions & Measures \\
\hline Q1 & $\begin{array}{l}\text { Do you gather issues for analysis? } \\
\text { (Issues are collected from reviews and } \\
\text { from execution of other processes) } \\
\text { (Issues including: significant derivation } \\
\text { in project planning parameters, } \\
\text { commitments that have not been } \\
\text { satisfied, significant changes in risk } \\
\text { status, security issues, and stakeholder } \\
\text { involvement issues) }\end{array}$ & $\bullet$ \# Issues. \\
\hline Q2 & $\begin{array}{l}\text { Do you analyze issues to determine the } \\
\text { need for corrective actions? } \\
\text { (if issues are not resolved by a corrective } \\
\text { actions the project may be prevented } \\
\text { from meeting its objectives ) }\end{array}$ & $\begin{array}{l}\text { • Analyzing issues to determine the need } \\
\text { for corrective actions. }\end{array}$ \\
\hline
\end{tabular}

\subsection{Measures for specific practice 9}

Take Corrective Action: Take corrective action on identified issues. A set of questions and measures is given in the next table concerning specific practice 9 .

Table 9. Set of questions and measures concerning specific practice 9

\begin{tabular}{|l|l|l|}
\hline & Questions & Measures \\
\hline Q1 & $\begin{array}{l}\text { Do you determine and document the } \\
\text { appropriate actions to address identified } \\
\text { issues? }\end{array}$ & $\begin{array}{l}\bullet \text { Determining and documenting the } \\
\text { appropriate actions to address identified } \\
\text { issues. } \\
\text { (Examples of actions include: modifying } \\
\text { requirement, revising estimates and plans, } \\
\text { renegotiating commitments, adding } \\
\text { resources, and revising project risks). }\end{array}$ \\
\hline Q2 & $\begin{array}{l}\text { \# Corrective actions to address identified } \\
\text { issues. } \\
\text { relevant stakeholders on the actions? }\end{array}$ & $\begin{array}{l}\bullet \text { Reviewing and getting agreement with } \\
\text { relevant stakeholders on the actions. }\end{array}$ \\
\hline
\end{tabular}




\subsection{Measures for specific practice 10}

Manage Corrective Actions: Manage corrective actions to closure.

A set of questions and measures is given in the next table concerning specific practice 10.

Table 10. Set of questions and measures concerning specific practice 10

\begin{tabular}{|l|l|l|}
\hline Q1 & $\begin{array}{l}\text { Questions } \\
\text { Do you monitor corrective actions for } \\
\text { completion? }\end{array}$ & $\begin{array}{l}\text { Measures } \\
\text { Monitoring corrective actions for } \\
\text { completion. } \\
\text { —\# Monitored corrective actions. }\end{array}$ \\
\hline Q2 & $\begin{array}{l}\text { Do you analyze the results of corrective } \\
\text { actions to determine the effectiveness? }\end{array}$ & $\begin{array}{l}\text { - Analyzing the results of corrective } \\
\text { actions to determine the effectiveness. } \\
\text { —\# Monitored corrective actions. }\end{array}$ \\
\hline Q3 & $\begin{array}{l}\text { Do you determine and document } \\
\text { appropriate actions to correct deviations } \\
\text { from the planned results? }\end{array}$ & $\begin{array}{l}\text { - Determining and documenting } \\
\text { appropriate actions to correct deviations } \\
\text { from the planned results. } \\
\text {-\# Deviations from the planned results. }\end{array}$ \\
\hline
\end{tabular}

\section{VALIDITY AND RELIABILITY OF THE DEFINEd MEASURES}

We have made a questionnaire to examine the validity and reliability of the measures we defined for Project Monitoring and Control PA and confirm that they are actually measure the ten specific practices. We will analyze the collected data by cronbach alpha reliability in SPSS.

The questionnaire was reviewed and confirmed by practitioners in software developing and academics in software engineering in Zarqa University. The questionnaire was filled by software engineers, system designers, and students in computer information system department. The questionnaire consists of ten parts, each part is related to one of the ten specific practices of the Project Monitoring and Control process, each part consists of a group of statements (measures) related to the specific practice, alongside each statement there is five options: strongly agree, agree, neither agree nor disagree, disagree, strongly disagree. The questioner reads the statement then he will write his view of the statement relation with the specific practice by choosing one of the above five options, a sample shown in Appendix A.

Cronbach alpha is used to measure the internal consistency, which means, do all items measure the same thing? (Measure a single unidirectional structure). Values of Cronbach alpha are varying between 0 and 1, if alpha is closer to 1 , then there is a greater internal consistency of items being assessed [15]. If Cronbach alpha is less than 0.5 then internal consistencies is rejected [15]. After we apply the collected data on Cronbach Alpha we found alpha results between less than 1 and over 0.5 .

\section{CONCLUSION}

Our paper defined general measures for Project Monitoring and Control Process Area (PA) in Capability Maturity Model Integration (CMMI-SW) for software development. We defined the 
International Journal of Computer Science \& Information Technology (IJCSIT) Vol 5, No 5, October 2013

measures by applying the Goal Question Metrics (GQM) paradigm to the two specific goals and its ten specific practices of Project Monitoring and Control PA. Our paper focused on defining measures for a specific process area rather than defining measures for many process areas together.

The set of defined measures in the paper provide the organization with better insight into the activities related to Project Monitoring and Control, enhancing the development of software to the goal of having a matured process. The set of measures can be used to evaluate and control software products and processes. Using of the defined measures depends on the maturity of the software development process in the organization.

\section{REFERENCES}

[1] Ahern, D. M., Clouse, A. and Turner, R., CMMI Distilled: A Practical introduction to Integrated Process Improvement. Second edition, Addison - Wesley, 2003.

[2] Barreto A. and Rocha A., Defining and Monitoring Strategically Aligned Software Improvement Goals, Product-Focused Software Process Improvement, Volume 6156, pp 380-394,2010, Springer.

[3] Barreto A. and Rocha A., Analyzing the Similarity among Software Projects to Improve Software Project Monitoring Processes, 2010 Seventh International Conference on the Quality of Information and Communications Technology (IEEE QUATIC 2010).

[4] Basili, V. R. and Rombach, H. D., "The TAME Project: Towards Improvement-Oriented Software Environments", in IEEE Transactions on Software Engineering, vol. 14, no. 6, pp.758-773, 1988.

[5] Basili, V. R., Caldiera, C., Rombach, H. D., Goal Question Metric Paradigm, Encyclopedia of Software Engineering (Marciniak, J.J., editor), volume 1, John Wiley \& Sons, pp. 528-532, 1994.

[6] Basili, V. R., and Weiss, D. M., "A Methodology for collecting Valid Software Engineering Data", in IEEE Transactions on Software Engineering, volume. SE-10, pp.728-738, 1984.

[7] Baumert, J. H. and McWhinney, M. S., Software Measures and the Capability Maturity Model, Software Engineering Institute Technical Report, CMU/SEI-92-TR-25, ESC-TR-92-0, 1992.

[8] Briand, L.C., Morasca, S., and Basili, V. R., "An Operational Process for Goal Driven Definition of Measures", in IEEE Transactions on Software Engineering, vol. 28, no. 12, 2002.

[9] Curtis, B., Hefley, W. E., Miller, S. The People Capability Model : Guidelines for Improving the Workforce. Boston : Addison Wesley, 2001.

[10] Ebert, C. , Software Measurement for Better Project and Process Quality, UPGRADE (the European Journal for the Informatics Professional), Vol. x, No. 5, October, 2009.

[11] Ejiogu, L. O., " Five Principles for the Formal Validation of Models of Software Metrics “, ACM SIGPLAN Notices, Vol. 28,No. 8, August 1993.

[12] Fenton, N.E., and Pfleeger, S.L., Software Metrics - A Rigorous \& Practical Approach, 2nd Edition, International Thomson Publishing, Boston, MA, 1996.

[13] Fenton, N. E. \& Whitty, R. and Yoshinori, I. Software Quality Assurance and Measurement, A Worldwide Perspective. London: International Thomson Computer Press, 1995.

[14] Filipe, J., Shishkoy, B., Helfert, M. (Eds.): A Systematic Review Measurement in Software Engineering: State-of-the-Art in Measurement, RICSOFT 2006, CCIS vol. 10, pp. 165-176, 2008. (c) Springer-Verlag Berlin Heidelberg 2008.

[15] George, D. and Mallery, P., SPSS for windows step by step A Simple Guide and Reference, Fourth Edition, 2003.

[16] Hammer T. F., Huffman L. L., and Rosenberg L. H, "Doing requirements right the first time", in CROSSTALK, The Journal of Defence Software Engineering, December, pp. 20-25, 1998.

[17] Jacquet, J. P. and Abran, A., "Metric Validation Proposals, A structured Analysis", 8th International Workshop on Software Measurement, Germany, Sept. 17-18, 1998.

[18] Janakiram. D and Rajasree. M. S, "ReQuEst: Requirements-driven Quality Estimator", in ACM SIGSOFT Software engineering notes, vol. 30, no.1, 2005. 
International Journal of Computer Science \& Information Technology (IJCSIT) Vol 5, No 5, October 2013

[19] Jones, C. , Implementing a Successful Measurement Program: Tried and True Practices and Tools, Cutter IT Journal, Vol. 11, No. 5, November, 2003.

[20] Khraiwesh, M., Requirements Validation Measures in CMMI, Mahmoud Khraiwesh, World of Computer Science and Information Technology Journal (WCSIT), Vo.1, No. 2, 26-33, 2011.

[21] Khraiwesh, M., Risk Management Measures in CMMI, International Journal of Software Engineering \& Applications (IJSEA), Vo. 3, No. 1, 149-163, January 2012.

[22] Khraiwesh, M., Project Planning Measures in CMMI, International Journal of Software Engineering \& Applications (IJSEA), Vo. 4, No. 2, 103-121, March 2013.

[23] Kitchenham, B., Pfleeger, S.L., and Fenton, N., Towards a Framework for Software Measurement Validation, in IEEE Transactions on Software Engineering, 21(12), December 1995.

[24] Kitchenham, B. and Jeffery, D., Misleading Metrics and Unsound Analyses, in IEEE Software, April 2007. nstability on Software Defects, in ACM Software engineering notes, 2004, vol. 29, no. 4.

[25] Lee, Y, and Chen, J. Experience in introducing CMM to a telecommunication research organization, Journal of Software Engineering Studies, vol.1, No. 1, 8-16, September 2006.

[26] Loconsole, A., "Measuring the Requirements Management Key Process Area", Proceedings of ESCOM - European Software Control and Metrics Conference, London, UK, April, 2001.

[27] Mahinc, V. and Zabkar, N. Measurement repository for Scrum-based software development process. Conference on computer Engineering and Application (CEA,08) Acapulco, Mexico, January 25-27, 2008.

[28] McBride T., Henderson-Sellers B., and Zowghi D., "Software development as a design or a production project: An empirical study of project monitoring and control", Journal of Enterprise Information Management, Vol. 20 Iss: 1, pp.70 - 82, 2007.

[29] Park, R. E., Goethert, W. B. and Florac, W. A., Goal-Driven Software Measurement-A Guidebook, Software Engineering Institute Handbook, CMU/SEI-96- HB-002, August, 1996.

[30] Paulk, M. C., Weber, C. V., Garcia, S., Chrissis, M. B., and Bush, M., Key Practices of the Capability Maturity Model Version 1.1, Software Engineering Institute Technical Report, CMU/SEI-93- TR-25 ESC-TR-93-178, Pittsburgh, PA, USA, February, 1993.

[31] Pressman, R. S., Software engineering: A practitioner's Approach, Sixth edition, 2005.

[32] Ponisoi L. and Vruggink P., Effective Monitoring and Control of Outsourced Software Development Projects, Information Systems Development, pp 135-147, 2011, Springer.

[33] Pyster A., What Beyond CMMI Is needed to Help Assure Program and Project Success, SPW 2005, LNCS 3840, pp. 75 - 82, 2005. () Springer-Verlag Berlin Heidelberg 2005.

[34] SEI (software Engineering Institute), CMMI (Capatility Maturity Model-Integrated) for development, V,1.2, Carnegie Mellon University, August 2006.

[35] Tihinen M., Parviainen P., Suomalainen T., Karhu K., and Mannevaara M., ABB Experiences of Boosting Controlling and Monitoring Activities in Collaborative Production, 2011 Sixth IEEE International Conference on Global Software Engineering ( IEEE ICGSE 2011).

[36] Wu, C. S. , Simmons D. B., Software project planning Associate(SPPA): a knowledge based approach for dynamic software project planning and tracking, 24th International Computer Software and Application conference, (COMPSAC), Taiwan, October, 2000.

[37] Xiong W., and Cao Y., Comments on Software Process Improvement Methodologies Using QFD, Applied Mathematics \& Information Sciences Journal, Vol. 7, No. 3, 1137-1143, 2013.

[38] Young, H., Fang, T., and Hu, C. A successful practice of applying software tools to CMM1 process improvement, Journal of Software Engineering Studies, vol. 1, No. 2, 78-95, December 2006. 
International Journal of Computer Science \& Information Technology (IJCSIT) Vol 5, No 5, October 2013

\section{Appendix A}

\section{Questionnaire and Analysis}

\section{Questionnaire:}

This questionnaire is related to the Project Monitoring and Control process. Project Monitoring and Control process provides an understanding of the project's progress so that appropriate corrective actions can be taken when the project deviates significantly from the plan..

The Project Monitoring and Control process has ten goals:

1-Monitor Project Planning Parameters.

2- Monitor Commitments.

3- Monitor Project Risks.

4- Monitor Data Management.

5- Monitor Stakeholder Involvement.

6- Conduct Progress Reviews.

7- Conduct Milestone Reviews.

8- Analyze Issues.

9- Take Corrective Action.

10- Manage Corrective Actions.

We would like to measure the accomplishment of the above goals, thus, we define some sentences related to each goal. We suppose that the information in these sentences help us in accomplishment of the above ten goals.

Please, fill the enclosed form by writing $\sqrt{ }$ in the suitable place. Responding to this question: do you think that the statements have an effect on the achievement of the goals?

1. Goal1: Monitor Project Planning Parameters.

(do you think that these sentences have an effect on the accomplishment of goal1: Monitor Project Planning Parameters.)

\begin{tabular}{|l|l|l|l|l|l|l|}
\hline $\begin{array}{l}\text { stateme } \\
\text { st } \\
\text { serial }\end{array}$ & statements & $\begin{array}{l}\text { Strongl } \\
\text { agree }\end{array}$ & Agree & $\begin{array}{l}\text { Neither } \\
\text { agree nor } \\
\text { disagree }\end{array}$ & $\begin{array}{l}\text { disagre } \\
\mathrm{e}\end{array}$ & $\begin{array}{l}\text { Strongly } \\
\text { disagree }\end{array}$ \\
\hline 1 & $\begin{array}{l}\text { Monitoring the } \\
\text { project planning } \\
\text { parameters to the } \\
\text { project plan. }\end{array}$ & & & & & \\
\hline 2 & $\begin{array}{l}\text { Monitoring the } \\
\text { project progress } \\
\text { against the } \\
\text { schedule. }\end{array}$ & & & & & \\
\hline 3 & $\begin{array}{l}\text { Monitoring } \\
\text { periodically the } \\
\text { actual completion }\end{array}$ & & & & & \\
\hline
\end{tabular}


International Journal of Computer Science \& Information Technology (IJCSIT) Vol 5, No 5, October 2013

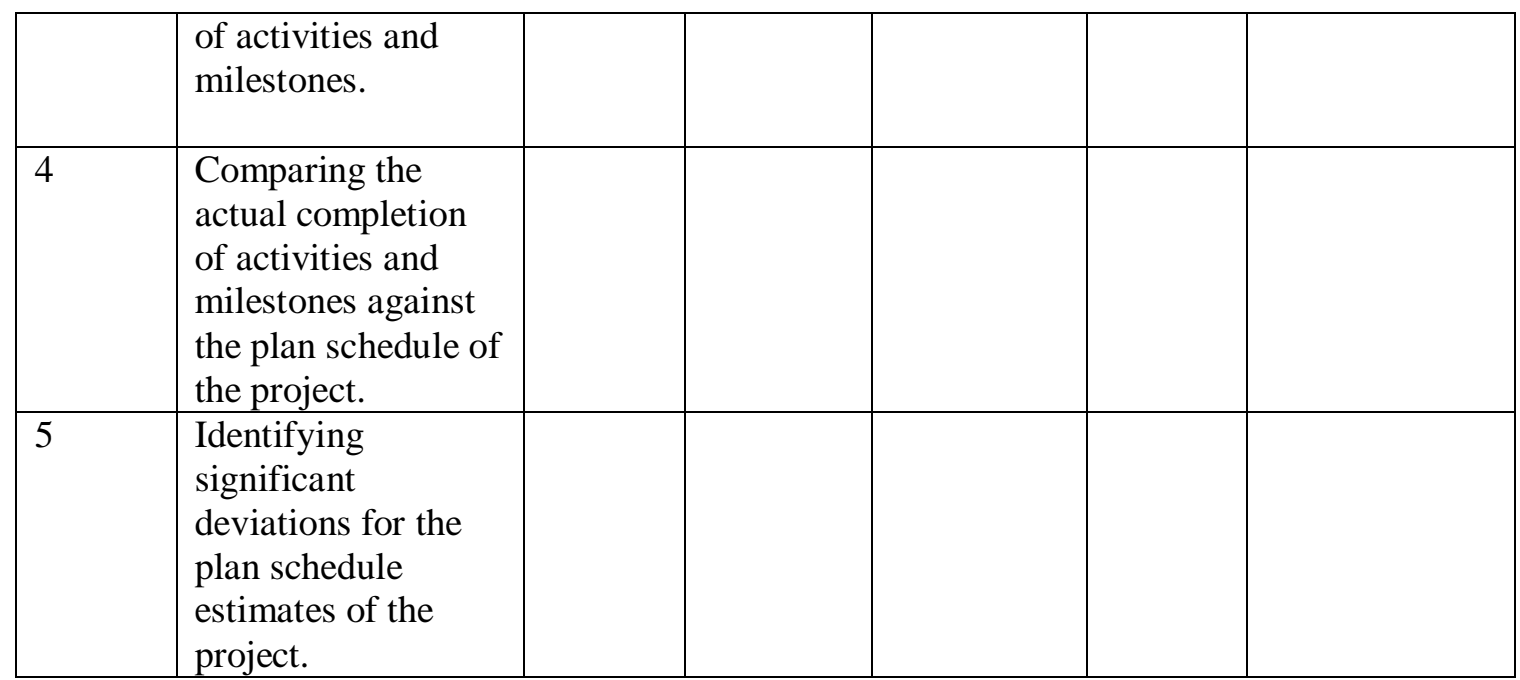

\section{Authors}

Mahmoud khraiwesh is an associate professor at Faculty of Science and Information Technology in Zarqa University, Jordan. He got his master degree in computer science from Jordan University, Jordan, in 2002 and his doctorate degree in computer information system from The Arab Academy for Banking and Financial sciences, Jordan, in 2006. His area of research is in software development measures.

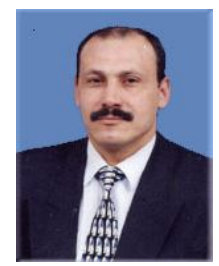

